\title{
Penggunaan kombinasi Gonadotropin untuk pengobatan hipofungsi ovarium pada sapi perah
}

\section{Application of Gonadotropin combination for ovarian hypofunction therapy in dairy cows}

\author{
Novia Alfi Masruro $^{1 *}$, Sri Mulyati ${ }^{2}$, Nenny Harijani $^{3}$, Sri Pantja Madyawati $^{2}$, \\ Abdul Samik ${ }^{2}$, Hermin Ratnani \\ ${ }^{1}$ Mahasiswa, ${ }^{2}$ Departemen Reproduksi Veteriner, ${ }^{3}$ Departemen Kesehatan Masyarakat Veteriner \\ Fakultas Kedokteran Hewan Universitas Airlangga \\ *Penulis koresponden, e-mail: Alfinovia@gmail.com
}

\begin{abstract}
This case report aims to determine the response of estrus and pregnancy rates in dairy cows with ovarian hypofunction by administering a combination of gonadotropin hormones. The sample used was ten dairy cows that had been calving, were not pregnant, showed no signs of estrus for more than 60 days after the last calving and had ovarian hypofunction based on rectal palpation. All dairy cows were injected 300 IU PG-600, then divided into two groups, each injected with 100 and 300 IU hCG respectively for first group and second group, intramuscularly at the time of insemination. The results showed that the estrus response occurred in all cows, in 6-8 (6.8 \pm 0.84$)$ days (first group), and 6-7 (6.2 \pm 0.45$)$ days (second group). Trans-rectal palpation pregnancy diagnosis 60 days after artificial insemination showed that all dairy cows in both groups were pregnant. It could be concluded that the treatment of dairy cows suffering from ovarian hypofunction with a combination of 300 IU PG-600 and 100 IU hCG was sufficient to induce 100\% estrus rates and $100 \%$ pregnancy rates.
\end{abstract}

Keywords: ovarian hypofunction, dairy cattle, artificial insemination, pregnancy rates

\section{PENDAHULUAN}

Peternakan sapi perah di Indonesia sebagian besar dilakukan oleh anggota masyarakat di pedesaan secara perorangan yang bergabung dalam suatu koperasi. Koperasi Serba Usaha (KSU) Tunas Setia Baru berada di Kecamatan Tutur Kabupaten Pasuruan, Jawa Timur, dengan jumlah populasi sapi perah yang dimiliki anggotanya 1.326 ekor induk sapi, perSeptember 2018. Permasalahan pada usaha ternak sapi perah pada umumnya adalah rendahnya efisiensi reproduksi yang disebabkan oleh gangguan reproduksi. Data laporan kasus gangguan reproduksi sapi perah di KSU Tunas Setia Baru yang cukup banyak adalah hipofungsi ovarium.

Data global gangguan reproduksi pada sapi dan kerbau tahun 2002-2017, kasus hipofungsi ovarium menempati persentase kedua terbanyak (12\%) setelah sub-estrus $(42,1 \%)$ (Yániz et al., 2008). Sedangkan di beberapa wilayah yang lain kasus hipofungsi ovarium menempati persentase teringgi diantara kasus gangguan reproduksi yang lain meskippun dengan angka yang berbeda-beda, yaitu di Lithuania $15,87 \%$ (Juodžentytė dan Žilaitis, 2018), di Sulawesi $62,1 \%$ (Wahyuni et al., 2018), dan di Jawa Timur sebesar 6,28\% (Hermadi et al., 2017).

Pada kasus hipofungsi ovarium tidak ada folikel mapupun korpus luteum, sehingga pada pemeriksaan per rektal permukaan ovarium licin. Sapi yang mengalami hipofungsi ovarium tidak menunjukkan tanda-tanda birahi (anestrus) dalam waktu yang lama. Secara endokrinoligis kasus hipofungsi terutama terjadi akibat kekurangan nutrisi, sehingga kelenjar hipofisa anterior tidak mampu mensekresikan 
Follicle Stimulating Hormone (FSH) dalam jumlah yang cukup untuk pertumbuhan dan pembentukan folikel di ovarium. Penanganan pada keadaan hipofungsi ovarium dapat dilakukan dengan memperbaiki kualitas pakan dan pemberian pengobatan dengan hormon antara lain dengan hormon gonadotropin (Hariadi et al., 2011).

Hormon gonadotropin yang banyak dipergunakan oleh para praktisi adalah Pregnant Mare Serum Gonadotropin (PMSG) dan human Chorionic Gonadrotopin (hCG). Kedua hormon tersebut merupakan hormon glikoprotein, terdiri dari subunit $\alpha$ dan $\beta$. Sub unit $\alpha$ pada PMSG dan hCG adalah sama, namun sub unit $\beta$ yang menimbulkan perbedaan sifat aktivitasnya. Hormon PMSG berfungsi seperti Follicle Stimulating Hormone (FSH) yang merangsang pertumbuhan folikel sampai matang sehingga menimbulkan gejala birahi, dengan sedikit sifat Luteinizing Hormon (LH) yang berfungsi menyebabkan ovulasi pada folikel yang telah matang (González-Menció et al., 1978; Ismudiono et al., 2010), sedangkan hormon hCG bekerja seperti Luteinizing Hormon (LH) (Cole, 2009).

Laporan kasus ini membahas pengobatan hipofungsi ovarium menggunakan dosis yang sama hormon PMSG dikombinasikan dengan hormon hCG dengan dosis yang berbeda.

\section{MATERI DAN METODE}

\section{Lokasi kasus}

Koperasi Serba Usaha (KSU) Tunas Setia Baru Kecamatan Tutur Kabupaten Pasuruan, Jawa Timur, terletak di lereng sebelah barat pegunungan Tengger di ketinggian 400-2000 meter. Wilayah kerja KSU Tunas Setia Baru meliputi 10 desa, yang secara secara geografis berada pada $7^{\circ} 53^{\prime} 30.51^{\prime \prime}$ LS dan $112^{\circ} 48^{\prime}$ 41.90" BT.

\section{Diagnosis}

Laporan kasus menggunakan 10 ekor ternak sapi perah Peranakan Friesian Holstein $(\mathrm{PFH})$, dengan kriteria: pernah beranak, tidak menunjukkan gejala estrus lebih dari 60 hari setelah melahirkan terakhir (Hafez dan Hafez, 2000a), skor kondisi tubuh (Body Condition Score, BCS) 3 atau kurang (skala 1-5).
Diagnosis dengan pemeriksaan palpasi rektal untuk memastikan bahwa kondisi ovarium halus tanpa ada folikel maupun korpus luteum.

\section{Terapi Hormon}

Hormon yang digunakan adalah preparat hormon PG-600 (Intervet), preparat hormon hCG Chorulon (MSD). Sepuluh sapi perah yang mengalami hipofungsi ovarium disuntik PG600 dengan dosis 300 IU secara intramuskuler pada saat diagnosa hipofungsi ovarium ditegakkan. Selanjutnya 10 sapi perah hipofungsi ovarium tersebut dibagi secara acak menjadi dua kelompok sama banyak. Penyuntikan Chorulan (hCG) dilakukan secara inramuskuler pada waktu birahi bersamaan dengan saat inseminasi, yaitu 300 IU pada kelompok pertama, dan 600 IU pada kelompok kedua. Respons birahi yang diamati berupa persentase birahi, serta rentangan dan rerata waktu terjadinya birahi dihitung berdasarkan saat penyuntikan PG-600 sampai dengan munculnya tanda birahi, diantara spai perah yang mengalami hipofungsi ovarium.

\section{Inseminasi Buatan}

Inseminasi buatan dilakukan dengan menggunakan semen beku sapi perah PFH yang diperoleh dari Balai Besar Inseminasi Buatan (BBIB) Singosari. Teknis pelaksanaan dilakukan oleh inseminator, sesuai prosedur operasional standar, semen beku post-thawing dimasukkan pada posisi keempat menggunakan laras inseminasi buatan. Respons yang diamati adalah persentase kebuntingan diantara sapisapi diberi perlakuan dan diinseminasi.

\section{HASIL}

Semua sapi perah hipofungsi ovarium (100\%) mengalami birahi baik pada kelompok pertama maupun kelompok kedua. Waktu munculnya tanda-tanda birahi dihitung sejak penyuntikan PG-600 pada kelompok pertama pada rentangan $6-8$, dengan rerata $6,8 \pm 0.84$, sedangkan pada kelompok kedua pada rentangan $6-7$ dengan rerata $6,2 \pm 0.45$ hari. Diagnosis kebuntingan yang dilakukan 60 hari setelah inseminasi buatan menunjukkan bahwa semua sapi perah PFH (100\%) pada kedua kelompok tersebut dinyatakan bunting (Tabel $1)$. 
Tabel 1 Persentase birahi, rentangan dan rerata waktu munculnya birahi (hari), serta persentase kebuntingan pada sapi perah yang mengalami hipofungsi ovarium setelah diberi pengobatan dengan hormon gonadotropin.

\begin{tabular}{|c|c|c|c|c|c|c|}
\hline \multicolumn{2}{|c|}{ Gonadotropin } & \multirow{2}{*}{$\begin{array}{c}\text { jumlah } \\
\text { sapi }\end{array}$} & \multicolumn{3}{|c|}{ birahi } & \multirow{2}{*}{$\begin{array}{l}\text { persentase } \\
\text { bunting }\end{array}$} \\
\hline PG-600 & $\mathrm{hCG}$ & & persentase & rentangan waktu & rerata waktu & \\
\hline $300 \mathrm{IU}$ & $100 \mathrm{IU}$ & 5 & $100 \%(5 / 5)$ & $6-8$ & $6,8 \pm 0.84$ & $100 \%(5 / 5)$ \\
\hline $300 \mathrm{IU}$ & $300 \mathrm{IU}$ & 5 & $100 \%(5 / 5)$ & $6-7$ & $6,2 \pm 0.45$ & $100 \%(5 / 5)$ \\
\hline
\end{tabular}

PG-600 disuntikkan intramuskuler saat sapi terdiagnosis hipofungsi ovarium; hCG disuntikkan bersamaan dengan waktu inseminasi buatan; waktu birahi dihitung dari saat penyuntikan sampai dengan pertama kali munculnya tanda birahi.

\section{DISKUSI}

Gangguan reproduksi karena hipofungsi ovarium dapat diobati dengan pemberian preparat hormonal FSH-LH like dengan penyuntikan preparat kombinasi FSH-LH atau FSH-LH like seperti, PMSG dan hCG (Hermadi, 2015). Pada penanganan kasus hipofungsi pada sapi perah di KSU Tunas Setia Baru menggunakan kombinasi PG-600 300IU dengan hCG 300IU atau kombinasi PG-600 dan hCG 100IU terbukti dapat mengaktifkan kembali ovarium pada $100 \%$ (10/10), sehingga semuanya menunjukkan respons birahi antara 6-8 hari setelah penyuntikan PG-600, dan semua bunting pada pemeriksaan per rektal 60 hari setelah dilakukan inseminasi buatan. Hasil tersebut lebih baik dibandingkan laporan-laporan sebelumnya. Pengobatan hipofungsi ovarium pada kerbau menggunakan PMSG saja menghasilkan kebuntingan $58.33 \%$ (ElKhadrawy et al., 2015). Sedangkan pengobatan hipofungsi ovarium pada sapi dan kerbau dengan 180 IU PG-600 saja menghasilkan angka birahi sebesar 90,8\%, antara 3 - 9 hari atau rata-rata 5 hari setelah penyuntikan PG600 (Wahyuni et al., 2018).

Preparat PG-600 mengandung 400 IU hormon PMSG dan 200 IU hormon hCG. Pregnant Mare Serum Gonadotropin mempunyai aktifitas sebagai FSH dan sedikit LH. Fungsi utama FSH adalah stimulasi pertumbuhan dan pematangan folikel de graaf di dalam ovarium (Bearden et al., 2004; Pemayun, 2009). Pada penanganan kasus ini, pemakaian kombinasi PG-600 dengan hCG mampu menginduksi aktivasi ovarium sapi yang mengalami hipufungsi. Hormon PMSG yang terkandung dalam PG-600 berfungsi menginisiasi pertumbuhan folikel pada ovarium. Sedangkan fungsi Luteinizing Hormone (LH) yang terkandung dalam PG-600 dan hCG berperan pada proses androgenesis yang terjadi pada folikel dengan merubah cholesterol menjadi testosterone. Testosteron yang terbentuk akan berdifusi masuk ke dalam sel granulosa untuk diubah oleh FSH menjadi estrogen melalui proses aromatisasi yang melibatkan enzim aromatase. Adanya estrogen menyebabkan pertumbuhan folikel muda menjadi matang sampai terjadi birahi yang diikuti ovulasi. Hormon estrogen juga menyebabkan sapi menunjukkan tanda-tanda birahi (Suartini et al., 2013).

Secara fisiologis fungsi FSH (dalam PG600) menstimulir pematangan folikel yang menghasilkan hormon estrogen. Hormon estrogen tersebut menyebabkan munculnya tanda-tanda birahi, yaitu peningkatan vaskularisasi ke organ reproduksi betina dan menimbulkan perilaku birahi. Ketika folikel telah matang, hormon estrogen mencapai kadar tertinggi yang kemudian memicu hipofisa anterior untuk melepaskan LH yang menyebabkan terjadinya ovulasi (Hafez dan Hafez, 2000b). Hormon hCG yang disuntikkan setelah penyuntikan PG-600 bertujuan untuk meningkatkan kapasitas induksi ovulasi. Hormon hCG mempunyai aktifitas seperti LH yang dapat merangsang sel-sel granulosa dan sel-sel teka pada folikel yang matang mengalami ovulasi (Siregar et al., 2004). Kebuntingan hasil inseminasi buatan tidak hanya karena aktivasi kembali ovarium sampai dengan terjadinya ovulasi, terdapat beberapa 
faktor lain yaitu kualitas semen, penanganan semen, deteksi birahi, ketepatan waktu inseminasi (Hastono dan Adiati, 2008) dan keterampilan inseminator dalam mendeposisikan semen ke dalam organ reproduksi sapi (Prayogo, 2008). Pada penanganan kasus ini faktor-faktor lain tersebut adalah sama diantara semua sapi perah objek pada laporan kasus ini. Setelah ovulasi, kadar hormon estrogen menurun drastic, sel-sel pada jaringan sisa ovulasi mengalami luteinasi oleh LH membentuk korpus luteum yang menghasilkan hormon progesterone. Sekresi LH yang terus menerus penting untuk mempertahankan CL dan sekresi progesteron untuk kelanjutan kebuntingan pada sapi (Bearden et al., 2004).

\section{KESIMPULAN}

Pemberian kombinasi hormon PMSG dengan hCG dapat menimbulkan birahi dan kebuntingan pada sapi perah 100\% (10/10) yang mengalami hipofungsi ovarium di KSU Tunas Setia Baru Kecamatan Tutur Kabupaten Pasuruan.

\section{PERSETUJUAN KOMISI ETIK}

Laporan kasus telah disetujui oleh Unit Penelitian Fakultas Kedokteran Hewan Universitas Airlangga (Nomor sertifikat persetujuan etis: 2.KE.054.04.2019)

\section{UCAPAN TERIMA KASIH}

Terima kasih kepada Koperasi Serba Usaha (KSU) Tunas Setia Baru, petugas kesehatan hewan dan beberapa peternak yang bekerja sama dan telah mengizinkan penggunaan ternak dan fasilitas yang ada. Terima kasih saya sampaikan pula kepada Prof. Dr. Sri Pantja Madyawati drh., M.Si. yang telah mengizinkan saya mengikuti penelitian ini, dan Ristek Dikti yang telah mendanai penelitian ini.

\section{DAFTAR PUSTAKA}

Bearden JH, Fuquay JW, Willard ST. 2004. Applied Animal Reproduction. 6th Ed. Pearson Education, Inc., Upper Saddle River. New Jersey.
Cole LA. 2009. New discoveries on the biology and detection of human Chorionic Gonadotropin. Reprod Biol Endocrinol. 7: 1-37.

El-Khadrawy HH, Ahmed WM, M.M. Zaabal MM and Hanafi EM. 2015. Lights on drugs used for treatment of ovarian disorders in farm animals. Global Veterinaria 14: 393-9.

González-Menció F, Manns J, and Murphy BD. 1978. FSH and LH activity of PMSG from mares at different stages of gestation. Anim Reprod Sci 1: 137-44.

Hafez ESE, Hafez B. 2000a. Anatomy of Male Reproduction. In: Reproduction in Farm Animals. Hafez and Hafez (Ed) 7th ed. Lippincott William \& Wilkins. A Wolter Kluwer Company.

Hafez ESE, Hafez B. 2000b. Folliculogenesis, egg maturation, and ovulation. In: Reproduction in Farm Animals. Hafez and Hafez (Ed) 7th ed. Lippincott William \& Wilkins. A Wolter Kluwer Company.

Hariadi M, Wurlina, Hermadi HA, Utomo B, Triana IN, Rimayanti, Ratnani H. 2011. Buku Ajar Ilmu Kemajiran. Penerbit Airlangga University Press. Surabaya. 126; 94-112.

Hastono H, Adiati U. 2008. Peningkatan Efisiensi Reproduksi Sapi Perah Melalui Kawin Tepat Waktu. Balai Penelitian Ternak. Bogor. 50

Hermadi HA, Hariadi M, Susilowati S. 2017. The ovarian hypofunction: a case in cow management therapy. Advances in Health Sciences Research (AHSR) 5. 1st International Conference in One Health (ICOH) 2017: 311-316.

Hermadi HA. 2015. Pemberantasan kasus kemajiran pada ternak menuju kemandirian di bidang kesehatan reproduksi hewan dan ketahanan pangan di Indonesia. Makalah Pidato Guru Besar. Pengukuhan Jabatan Guru Besar dalam Bidang Ilmu Kemajiran pada Fakultas Kedokteran Hewan Universitas Airlangga di Surabaya pada hari Sabtu, tanggal 25 April 2015.

Ismudiono, Srianto P, Anwar H, Madyawati SP, Samik A, Safitri E. 2010. Fisiologi Reproduksi pada Ternak. Universitas Airlangga Press. Surabaya. 
Juodžentytė R, Žilaitis V. 2018. Efficiency of dairy cows estrous cycle recovery after treatment of reproductive disorders. Vet Med Zoot 76: 25-9.

Pemayun TGO. 2009. Induksi estrus dengan PMSG dan GnRh pada sapi anestrus post partum. Buletin Veteriner Udayana 1: 83-7.

Prayogo TB. 2008. Peningkatan keberhasilan kebuntingan melalui modifikasi teknik deposisi semen pada sapi Peranakan Ongole (PO). Skripsi. Fakultas Peternakan Universitas Brawijaya. Malang.

Siregar TN, Areuby N, Riady G, Amiruddin. 2004. Efek pemberian PMSG terhadap respon ovarium dan kualitas embrio kambing lokal prepuber. Media Kedokteran Hewan 20: 108-12.

Suartini NK, TrilaksanaI GHB, Pemayun TGO. 2013. Kadar estrogen dan munculnya estrus setelah pemberian Buserelin (Agonis GnRH) pada sapi Bali yang mengalami anestrus postpartum akibat hipofungsi ovarium. Jurnal Ilmu dan Kesehatan Hewan
Wahyuni W, Purnama WH, Djatmikowati TF, Amaliah F, Samik A. 2018. Kombinasi hormon PMSG dan hCG untuk pengobatan kasus hipofungsi gangguan reproduksi pada sapi/kerbau di kegiatan UPSUS SIWAB 2017 di wilayah kerja Balai Besar Veteriner Maros. Prosiding Penyidikan Penyakit Hewan Rapat Teknis dan Pertemuan Ilmiah (RATEKPIL) dan Surveilans Kesehatan Hewan Tahun 2018: 514-22.

Yániz J, López-Gatius F, Bech-Sàbat G, GarcíaIspierto I, Serrano B, Santolaria P. 2008. Relationships between milk production, ovarian function and fertility in highproducing dairy herds in north-eastern Spain. Reprod Domest Anim. 43: 38-43. 